\title{
Mouse Model of the OPRMI (AI I8G) Polymorphism: Differential Heroin Self-Administration Behavior Compared with Wild-Type Mice
}

\author{
Yong Zhang*,', Roberto Picetti', Eduardo R Butelman', Ann Ho', Julie A Blendy ${ }^{2}$ and Mary Jeanne Kreek' \\ 'The Laboratory of the Biology of Addictive Diseases, The Rockefeller University, New York, NY, USA; '2Department of Pharmacology, Perelman \\ School of Medicine, University of Pennsylvania, Philadelphia, PA, USA
}

\begin{abstract}
Mu-opioid receptors (MOPRs) are the target of heroin and other prescription opioids, which are currently responsible for massive addiction morbidity in the US. The gene coding for the human MOPR (OPRMI) has an important functional single nucleotide polymorphism (SNP), AII8G. The OPRMI AII8G genotype results in substantially increased risk of heroin addiction in humans; however, the neurobiological mechanism for this increased risk is not fully understood. This study examined heroin self-administration (SA) behavior in A I I 2 G (G/G) mice, harboring a functionally equivalent SNP in Oprm / with a similar amino acid substitution, in extended (4 h) SA sessions. Adult male and female G/G mice and 'wild-type' litter mates (A/A) were allowed to self-administer heroin ( $0.25 \mathrm{mg} / \mathrm{kg} /$ unit dose, FRI with a nose poke response) for $4 \mathrm{~h} /$ day, for 10 consecutive days. Half of the mice then continued in a heroin doseresponse study, while extinction from heroin SA was studied in the other half. In vivo microdialysis was used to measure acute heroininduced increases of striatal dopamine in the GG vs AA genotypes. Male and female G/G mice responded for heroin significantly more (and thus had greater intake) than A/A mice, in the initial 10 days of heroin SA, and in the subsequent dose-response study. There were no significant differences in extinction of SA between the A/A and G/G mice. Heroin-induced increases in striatal dopamine levels are higher in the GG mice than in the AA mice. Both male and female G/G mice self-administered more heroin than did $A / A$ mice over a I0-day period, possibly because of the greater increases of heroin-induced striatal dopamine in the GG mice. Furthermore, $G / G$ male mice escalated the amount of heroin self-administration across 10 extended-access sessions more than A/A male mice did. These are the first studies to examine the acquisition of heroin SA in this mouse model. These studies may lead to a better understanding of the neurobiological and behavioral mechanisms that underlie greater risk of heroin addiction in carriers of the AII8G SNP.

Neuropsychopharmacology (2015) 40, I09I-I 100; doi:I0.I038/npp.2014.286; published online 7 January 2015
\end{abstract}

\section{INTRODUCTION}

Addiction to short-acting mu-opioid receptor (MOPR) agonists, such as heroin or prescription opioids (eg, oxycodone/Oxycontin, oxymorphone), is a chronic relapsing disease with massive personal and societal costs. The gene coding for the human MOPR (OPRM1) has an important functional single nucleotide polymorphism (SNP), A118G, resulting in an amino acid change from asparagine to aspartic acid at a putative glycosylation site (N40D) (Bond et al, 1998; Kreek et al, 2005). The OPRM1 A118G genotype (found in up to $30 \%$ of Caucasian and $60 \%$ of Asian populations) results in substantially increased risk of heroin addiction, based on genetic association studies (Bond et al, 1998; Kreek et al, 2005). A118G is a functional SNP,

\footnotetext{
*Correspondence: Dr Y Zhang, The Laboratory of the Biology of Addictive Diseases, The Rockefeller University, 1230 York Avenue, Box 17I, New York, NY 10065, USA, Tel: +212 327 8490, Fax: +212327 8574, E-mail: zhangyo@rockefeller.edu Received 27 March 2014; revised 20 August 2014; accepted 26 August 2014; accepted article preview online 22 October 2014
}

resulting in increased affinity and potency of the endogenous neuropeptide $B$-endorphin at MOPR (although this was not observed across all studies and methodologies), and reducing [3H] DAMGO (ie, MOPR) maximum binding (Bmax) in vitro (Bond et al, 1998; Zhang et al, 2005; Kroslak et al, 2007). A human postmortem study also found reduced OPRM1 mRNA expression, and reduced MOPR Bmax in subjects with the $118 \mathrm{G}$ allele (Zhang et al, 2005). A recent PET study also reported reduced MOPR binding potential in human carriers of the G allele (Weerts et al, 2013).

Although in vitro, clinical and postmortem studies have yielded valuable information regarding the role of the A118G SNP in association with addictions and opioid analgesia (for review, see LaForge et al, 2000; Kreek et al, 2005; Mague and Blendy, 2010), detailed neurobiological and behavioral analysis of the consequences of the A118G SNP can be approached in animal studies, particularly in order to understand the mechanistic role of the A118G SNP in addiction, modeling specific points in the trajectory of this disease.

Recently, a mouse possessing the equivalent SNP (A112G), which corresponds to a similar amino acid (N38D) 
substitution found in humans ( A118G; N40D) was generated (Mague et al, 2009). Studies with these mice have demonstrated that the $112 \mathrm{G}$ allele is associated with decreased MOPR mRNA levels and protein levels at baseline (Mague et al, 2009), similar to human $118 \mathrm{G}$ phenotypes (Zhang et al, 2005; Kroslak et $a l, 2007)$ and similarly eliminates a glycosylation site (Huang et al, 2012). These mice have an attenuated locomotor activation in response to acute morphine administration, fail to show sensitization of the locomotor response to repeated intermittent morphine administration, and have decreased morphine antinociceptive response (Mague et al, 2009). Interestingly, females homozygous for the $112 \mathrm{G}$ allele showed neither preference to morphine-associated environments nor aversion to environments associated with naloxone-precipitated withdrawal (Mague et al, 2009). Recent studies also show that there are sex- and neuroanatomical location-specific changes in MOPR populations in this mouse model at baseline (Wang et al, 2012a; Wang et al, 2012b). The impact of sex differences of the A118G SNP in human heroin addiction has not been reported to date.

The behavioral and neurobiological response of G/G mice to relatively high dose and long-duration self-exposure to a MOPR agonist in a paradigm mimicking addiction-like behavior has not been studied to date in these mice, or in another mouse modeling this SNP (Ramchandani et al, 2011). Therefore, the goals of this study were to examine whether there were any differences in heroin SA between the A/A and G/G male and female mice first, and to examine how heroin administration affects striatal dopamine in the A/A and G/G mice. We hypothesized that G/G mice would show alterations in heroin SA behavior and that AA and GG mice would display differences in heroin-induced increases in dopamine levels.

\section{MATERIALS AND METHODS}

\section{Mice}

Mating of A112G heterozygous mice (Mague et al, 2009) produced offspring of each genotype, but only A/A and G/G homozygous mice of both sexes were used for the behavioral experiments. Eleven to 12-week-old mice were housed in groups of four to five with free access to food and water in a light- (12:12 h light/dark cycle, light on at 7:00 pm and off at 7:00 am) and temperature- $\left(25^{\circ} \mathrm{C}\right)$ controlled room. Animal care and experimental procedures were conducted according to the Guide for the Care and Use of Laboratory Animals (Institute of Laboratory Animal Resources Commission on Life Sciences 1996). The experimental protocols used were approved by the Institutional Animal Care and Use Committee of The Rockefeller University.

\section{Self-Administration Procedure}

Catheter implantation. Mice were anesthetized with a combination of xylazine $(8.0 \mathrm{mg} / \mathrm{kg}$ i.p. $)$ and ketamine $(80 \mathrm{mg} / \mathrm{kg}$ i.p.). After shaving, and application of a $70 \%$ alcohol and iodine preparatory solution, incisions were made in the midscapular region and anteromedial to the forearm. A catheter approximately $6 \mathrm{~cm}$ in length (ID: $0.31 \mathrm{~mm}$, OD: $0.64 \mathrm{~mm}$ ) (Helix Medical, Inc. CA) was passed subcutaneously from the dorsal to the ventral incision. A 22-gauge needle was inserted into the right jugular vein to guide the catheter into the vein. The catheter was inserted to the level of a silicone ball marker, $1.1 \mathrm{~cm}$ from the end, and was tied to the vein with surgical silk. Physiological saline was then flushed through the catheter to avoid clotting, and the catheter then capped with a stopper. Antibiotic ointment was applied to the catheter exit wounds on the animal's back and forearm. Mice were group-housed after the surgery, and were allowed 5 days of recovery before being placed in operant test chambers for the SA procedure (Zhang et al, 2006; Zhang et al, 2013).

Intravenous SA chambers. SA chambers (ENV-307W; $21.6 \mathrm{~cm} \times 17.8 \mathrm{~cm} \times 12.7 \mathrm{~cm}$; Med. Associates, St Albans, VT) were located inside a larger box (Med. Associates). The front, back, and top were constructed of $5.6 \mathrm{~mm}$ polycarbonate. Each chamber contained a wall with two small holes $(0.9 \mathrm{~cm}$ diameter, $4.2 \mathrm{~cm}$ apart, $1.5 \mathrm{~cm}$ from the floor of the chamber). One hole was defined as active, the other was inactive (ie, a nose-poke therein was counted, but had no consequence). When the photocell in the active hole was triggered by a nose poke, the infusion pump (Med. Associates) delivered an infusion of $20 \mu \mathrm{l} / 3 \mathrm{~s}$ from a $5 \mathrm{ml}$ syringe. The syringe was connected by a swivel via Tygon tubing. The infusion pump and syringe were outside the chamber. During infusion, a cue light above the active hole was illuminated. Each injection was followed by a 20-s 'timeout' period during which poking responses were recorded but had no programmed consequences. All responses at the inactive hole were also recorded. Mice were tested during the dark phase of the diurnal cycle (all experiments were performed between 8:00 a.m. and 2:00 p.m.).

Heroin SA. A 4-h SA session was conducted once a day for 10 consecutive days. Each day, mice were weighed and heparinized saline $(0.01 \mathrm{ml}$ of $30 \mathrm{IU} / \mathrm{ml}$ solution $)$ was used to flush the catheter to maintain patency. During SA sessions, mice were placed in the SA chambers and a nose poke through the active hole led to an infusion of heroin (0.25 mg/kg/infusion; Sigma, St Louis, MO) under an FR1 schedule. Drug dose was controlled by a computer, which took into account the changes in an animal's body weight. Mice in the control groups received yoked saline infusions during all sessions (saline was infused in the control mouse whenever the heroin mouse self-administered heroin). At the end of the experiment, only data from mice that passed a catheter patency test, defined as loss of muscle tone within a few seconds after administration of $30 \mu$ l ketamine $(5 \mathrm{mg} / \mathrm{ml})$ (Fort Dodge, IA), were included in the analysis of data. Of a total 200 mice that started in the studies, 96 mice finished the 10-day heroin SA or yoked saline sessions, 10 -day dose response or extinction studies, and passed the catheter patency test. Data from these 96 mice are presented in the manuscript.

\section{In Vivo Microdialysis}

Surgical procedure. After at least 1 week of acclimation to their housing conditions, separate groups of mice were anaesthetized with a combination of xylazine $(8.0 \mathrm{mg} / \mathrm{kg}$ i.p. $)$ and 
ketamine $(80 \mathrm{mg} / \mathrm{kg}$ i.p. $)$ and were placed in a stereotaxic frame modified for the mouse (David Kopf, Topanga, CA) for implantation of a guide cannula. A guide cannula (CMA/7, North Chelmsford, MA) was implanted into the striatum (coordinates from Bregma: $A=0.65 \mathrm{~mm}$, $\mathrm{L}= \pm 2.00 \mathrm{~mm}$ and $\mathrm{V}=3.00 \mathrm{~mm}$ (Franklin and Paxinos, 1997)). The guide cannula was fixed to the skull by dental acrylic. Mice were allowed 4-5 days to recover from surgery before microdialysis.

In vivo microdialysis. Dialysis probes $(2 \mathrm{~mm}$ in length, o.d. $=0.24 \mathrm{~mm})(\mathrm{CMA} / 7)$ were calibrated for dopamine recovery in vitro before each experiment, as described previously (eg, Maisonneuve, 1994; Zhang et al, 2001, 2003). The day before the microdialysis experiment, mice were individually placed into microdialysis chambers (CMA/120) with free access to food and water to allow them to acclimate to the microdialysis chamber. Dialysis probes were then lowered into the striatum and were perfused with artificial cerebrospinal fluid $(146 \mathrm{mM} \mathrm{NaCl}, 2.7 \mathrm{mM}$ $\left.\mathrm{KCl}, \quad 1.2 \mathrm{mM} \quad \mathrm{CaCl}_{2}, 1.0 \mathrm{mM} \quad \mathrm{MgCl}_{2}\right)$ at $1.0 \mu \mathrm{l} / \mathrm{min}$ overnight. Following the overnight stabilization period (15 to $16 \mathrm{~h}$ ), basal levels of dialysate were collected from the freely moving mice every $20 \mathrm{~min}$ for $1 \mathrm{~h}$ at a flow rate of $1.0 \mu \mathrm{l} / \mathrm{min}$. After collection of baseline samples, each mouse received heroin administration i.p., first $10 \mathrm{mg} / \mathrm{kg}$, then an hour later $20 \mathrm{mg} / \mathrm{kg}$. Dialysate samples were collected every $20 \mathrm{~min}$ for $1 \mathrm{~h}$ after each heroin administration. All collecting tubes contained perchloric acid and EDTA as preservatives. Samples $(20 \mu \mathrm{l}$ each $)$ were immediately frozen and stored at $-80{ }^{\circ} \mathrm{C}$ until used for dopamine analysis. All experiments were performed between 8:00 a.m. and 2:00 p.m. in the light portion of the light/dark cycle.

Determination of dialysate dopamine levels. HPLC with electrochemical detection (ESA, North Chelmsford, MA) was used to measure dopamine concentration in the dialysates. The HPLC system consisted of an ESA 540 autosampler, an ESA 582 solvent delivery system, a reverse phase C18 column, and an ESA microdialysis cell (Model 5014B). The mobile phase was delivered at a rate of $0.5 \mathrm{ml} / \mathrm{min}$. Chromatograms were integrated and compared with standards using the ESA 501 chromatography system.

\section{Histological Verification of Probe Placement}

At the end of each microdialysis study, the mouse was decapitated following brief $\mathrm{CO}_{2}$ exposure, and its brain was removed. The brain was used for histological evaluation of probe placement. Frozen sections were cut to verify the correct placement of dialysis probes following acetyl cholinesterase labeling (see Franklin and Paxinos, 1997). Figure $7 \mathrm{c}$ is a photomicrograph of a tissue section from a mouse used in this study and shows the location of the microdialysis probe in the striatum.

\section{Statistical Analysis}

Differences in self-administration measured as number of nose pokes in the active hole in each SA session across the 10 sessions were assessed by a four-way analysis of variance
(ANOVA), Genotype $\times$ Sex $\times$ Condition (Heroin SA, Yoked Saline Control) $\times$ Session (repeated measure). The doseresponse study was analyzed by a four-way ANOVA, Genotype $\times$ Sex $\times$ Dose $\times$ Session with repeated measures on the last two factors. Differences in dopamine levels after heroin administration were assessed by three-way ANOVA, Genotype $\times$ Sex $\times$ Condition (Basal, $10 \mathrm{mg}, 20 \mathrm{mg}$ heroin).

\section{RESULTS}

\section{Heroin SA in A/A and G/G Mice across 10 Daily Extended Access (4-h) Sessions}

Heroin SA behavior of male and female A/A and G/G mice is shown in Figure 1. Nose pokes at the active hole increased across the 10-day extended sessions in both sexes and in both genotypes, with G/G mice showing higher levels of heroin SA. Nose pokes at the inactive hole decreased across the 10 sessions.

Noncontingent nose-poke behavior of the yoked saline controls is shown in Figure 2. In contrast to the mice selfadministering heroin, the controls showed declining nose pokes across the 10 sessions, with no difference between genotypes.

Examining the nose-poke behavior at the active hole, a four-way ANOVA, Genotype $\times$ Sex $\times$ Condition (Heroin SA $v s$ Yoked Saline) $\times$ Session with repeated measures on the last factor showed a significant main effect of Genotype, $\mathrm{F}(1,88)=34.79, p<0.000001$, no significant main effect of Sex, $F<1.0$, a significant effect of Condition, $F(1,88)=$ 139.65, $p<0.000001$, and a significant main effect across Sessions, $\mathrm{F}(9,792)=8.90, p<0.000001$. Most importantly, there was a significant Genotype $\times$ Condition interaction, $\mathrm{F}(1,88)=26.02, p<0.000002$, which is shown in Figure 3 . Although Yoked Saline controls showed no significant difference in nose pokes between genotypes, G/G mice nose poked significantly more than A/A mice did, $p<0.0002$.

As differences in heroin-related effects have been reported in $\mathrm{G} / \mathrm{G}$ mice, separate analyses for males and for females of the nose poking behavior at the active hole were conducted including mice in the Heroin SA and in the Yoked Saline Control conditions.

\section{Heroin Self-Administration of Male A/A and G/G Mice}

Three-way ANOVA, Genotype $\times$ Condition $\times$ Session, showed that $G / G$ mice nose poked significantly more at the active hole than A/A mice did, $\mathrm{F}(1,45)=23.63, p<0.00002$ (Figure 1a). There were fewer responses in the Yoked Saline Control condition, $F(1,45)=74.97, p<0.000001$, and a significant main effect of Session, $F(9,45)=7.96$, $p<0.000001$ (Figure 2a). As in the overall analysis above, the Genotype $\times$ Condition interaction was significant, $\mathrm{F}(1,45)=18.05, p<0.0002$. That is, the greater nose poking of the G/G mice was found in the Heroin SA group, but was not seen in the Yoked Saline Controls.

\section{Heroin Self-Administration of Female A/A and G/G Mice}

Similarly, female G/G mice nose poked significantly more at the active hole than A/A mice did, $\mathrm{F}(1,43)=12.02, p<0.002$, with a significant change across Sessions, $F(9,387)=2.61$, 
Active Hole

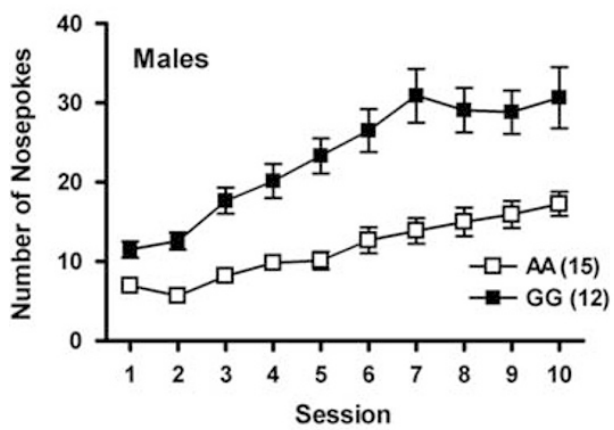

Inactive Hole

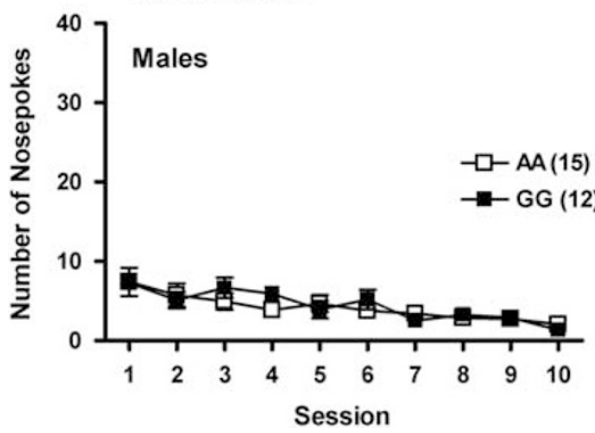

Active Hole

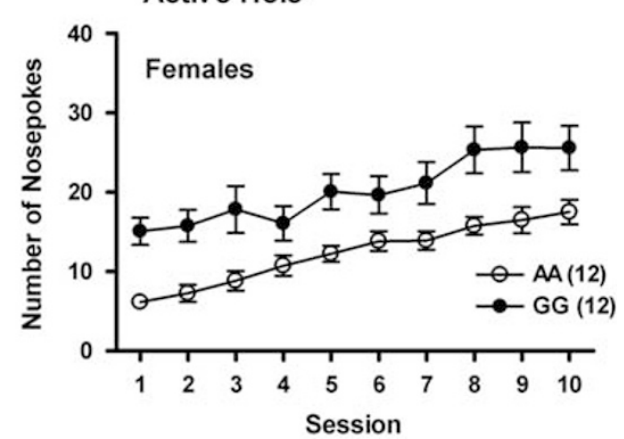

Inactive Hole

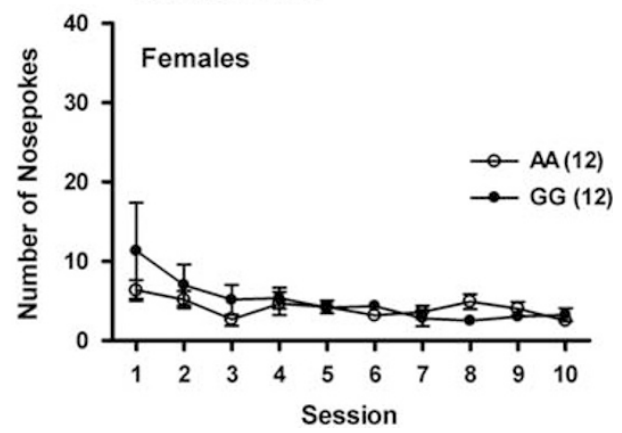

Figure I Heroin self-administration behavior of male and female A/A and G/G mice is shown. Nose pokes at the active hole increased across the I0-day extended sessions in both sexes and in both genotypes, with $\mathrm{G} / \mathrm{G}$ mice showing higher levels of heroin SA ( \pm SEM). Nose pokes at the inactive hole decreased across the 10 sessions.

$p<0.01$ (Figure 1b). There were fewer responses by mice in the Yoked Saline Control condition, $F(1,43)=64.93$, $p<0.000001$ (Figure 2b).

\section{G/G Mice Self-Administer more Heroin Across 10 Sessions than A/A Mice}

The total daily heroin self-administered across the 10 extended 4-h sessions is shown in Figure 4: males of each genotype in $\mathrm{A}$, females in each genotype in $\mathrm{B}$; the total amount of heroin taken across the 10 sessions is shown in C. A two-way ANOVA, Genotype $\times$ Sex showed that G/G mice of both sexes self-administered a greater total amount of heroin across 10-day sessions than did A/A mice, $\mathrm{F}(1,47)=39.27, \quad p<0.000001$. There was no significant effect of Sex, F $(1,47)<1.0$, nor was there a significant Genotype $\times$ Sex interaction, $F(1,47)=1.36$.

\section{Heroin Self-Administration Dose-Response Study}

Following the 10-days of heroin SA, a subset of mice were given access to a range of heroin doses: $0.001,0.0625,0.125$, $0.250 \mathrm{mg} / \mathrm{kg}$. Mice were allowed to self-administer each dose for two sessions in an ascending order. The mean number of nose pokes at each dose by each genotype is shown for each sex in Figure $5(0.001,0.0625,0.125,0.250 \mathrm{mg} / \mathrm{kg}$, mean $(+\mathrm{SEM})$ of two sessions at each dose). ANOVA showed that there was a significant effect of Genotype, $F(1,22)=$ 20.51, $p<0.0002$, a significant main effect of Sex,
$\mathrm{F}(1,22)=13.63, p<0.002$, and a significant main effect of Dose, $\mathrm{F}(1,66)=174.48, p<0.000001$. There was also a significant Genotype $\times$ Sex $\times$ Dose interaction effect, $F(3,66)=$ 5.96, $p<0.002$. As can be seen in Figure 5, G/G mice selfadministered more heroin at the three higher doses tested. At the lowest dose tested, G/G female mice self-administered significantly more heroin than did A/A females (B), but this genotypic difference was not found in the male mice (A).

\section{Extinction from Extended Access Heroin Self-Administration Sessions in A/A and G/G Mice}

Following the 10-days of heroin SA, a different subset of mice than those used in the dose-response experiments were examined for extinction behavior. Extinction from extended access heroin SA was carried out for over 10 sessions. Nose pokes at the formerly active hole across the 10 extinction trials are shown in Figure 6. A three-way ANOVA, Genotype $\times$ Sex $\times$ Trial showed that there was no significant differences between $A / A$ and $G / G$ mice, $\mathrm{F}(1,21)<1.0$, or between Sexes, $\mathrm{F}(1,21)=2.06$, with a significant decline over Trials, $\mathrm{F}(9,189)=5.13, p<0.000005$. Newman-Keuls post hoc tests showed that the nose pokes at the formerly active hole had declined significantly by the fourth extinction trial $(p<0.02)$ and was even lower by the tenth session $(p<0.00005)$. There were no significant interaction effects. Thus, extinction behavior of heroin selfadministration did not differ between the genotypes or sexes. 

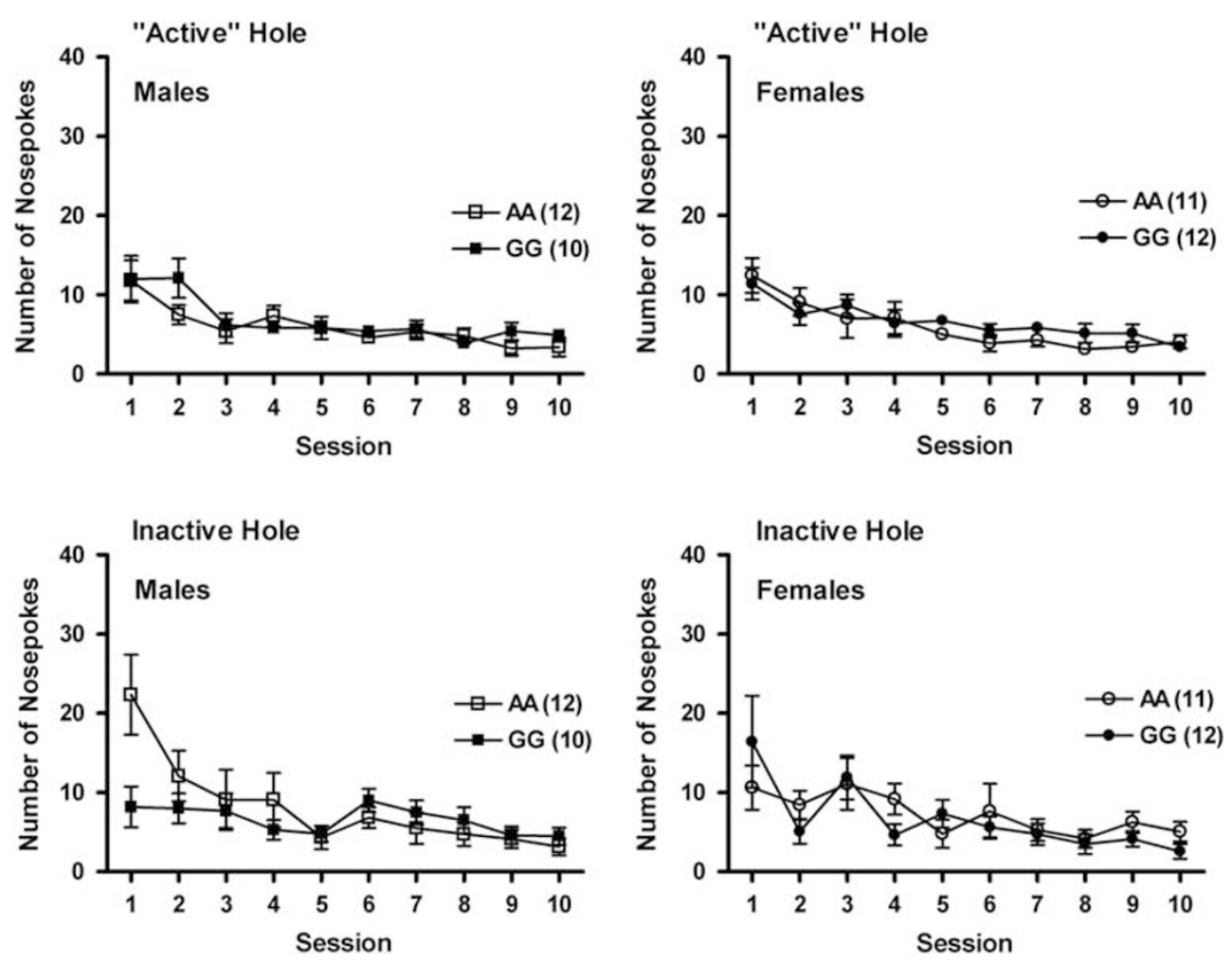

Figure 2 Non-contingent nose-poke behavior of the yoked saline controls. The controls showed declining nose pokes across the 10 sessions, with no difference between genotypes.

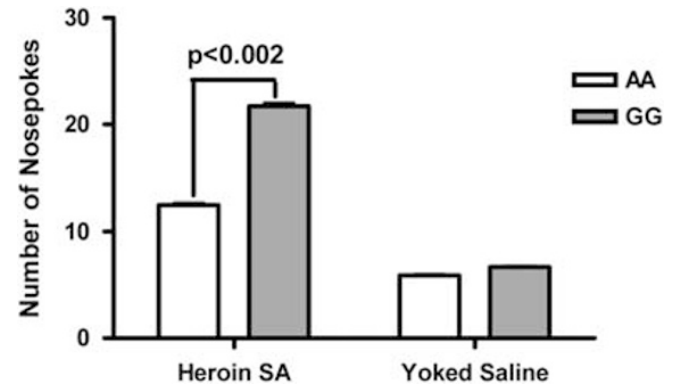

Figure 3 Nose-poke behavior at the active hole is shown. Although Yoked Saline controls showed no significant difference in nose pokes between genotypes, G/G mice nose poked significantly more than A/A mice for heroin $( \pm$ SEM).

\section{Effects of Acute Heroin Administration on Striatal Dopamine in A/A and G/G Mice}

The mean $( \pm$ SEM) levels of dopamine in the dialysate from the striatum during the baseline, and in the hour after each injection of heroin in both $\mathrm{A} / \mathrm{A}$ and $\mathrm{G} / \mathrm{G}$ male and female mice, are shown in Figure 7. As can be seen in Figure 7, baseline dopamine levels were similar among the AA and GG male and female mice. Dopamine levels induced by heroin injections were higher in the GG mice than in the AA mice.

The mean hourly concentrations of absolute dopamine levels of the basal samples, and absolute dopamine levels in response to each heroin injection are shown in Figure 8. Three-way ANOVA, Genotype $\times$ Sex $\times$ Condition (Basal, $10 \mathrm{mg}, 20 \mathrm{mg}$ ), with repeated measures showed that there was a significant main effect of Genotype, $F(1,21)=21.79$, $p<0.0002$, and a significant effect of Condition, $\mathrm{F}(2,42)=$ $212.38, p<0.00001$. Newman-Keuls tests showed that the $10 \mathrm{mg}$ heroin injection significantly increased dopamine levels compared with the baseline, $p<0.0002$, and the $20 \mathrm{mg}$ heroin injection increased dopamine even further, $p<0.0002$. There was also a significant Genotype $\times$ Condition interaction, F $(2,42)=16.48, \quad p<0.00001$. Planned comparisons showed that $10 \mathrm{mg}$ heroin-induced dopamine levels were higher in the G/G mice compared with the those of the A/A mice, $p<0.002$ and that $20 \mathrm{mg}$ heroininduced dopamine levels were also higher in the G/G mice than in the A/A mice, $p<0.00005$ (Figure 8a). Finally, there was also a significant Sex $\times$ Condition interaction, $\mathrm{F}(2,42)=4.90, p<0.02$ (as can be seen in Figure $8 \mathrm{~b}$ and $c$ ). A planned comparison showed that dopamine levels induced by $20 \mathrm{mg}$ heroin were higher in the female mice than the male mice, $p<0.05$; such an effect was not found at the $10 \mathrm{mg}$ heroin dose (Figure $8 \mathrm{c}$ ).

\section{DISCUSSION}

The current study examined heroin SA behavior in mice possessing a functionally analogous nucleotide/amino acid substitution in MOPR receptor gene to that of the human OPRM1 A118G SNP. This human SNP has received much 

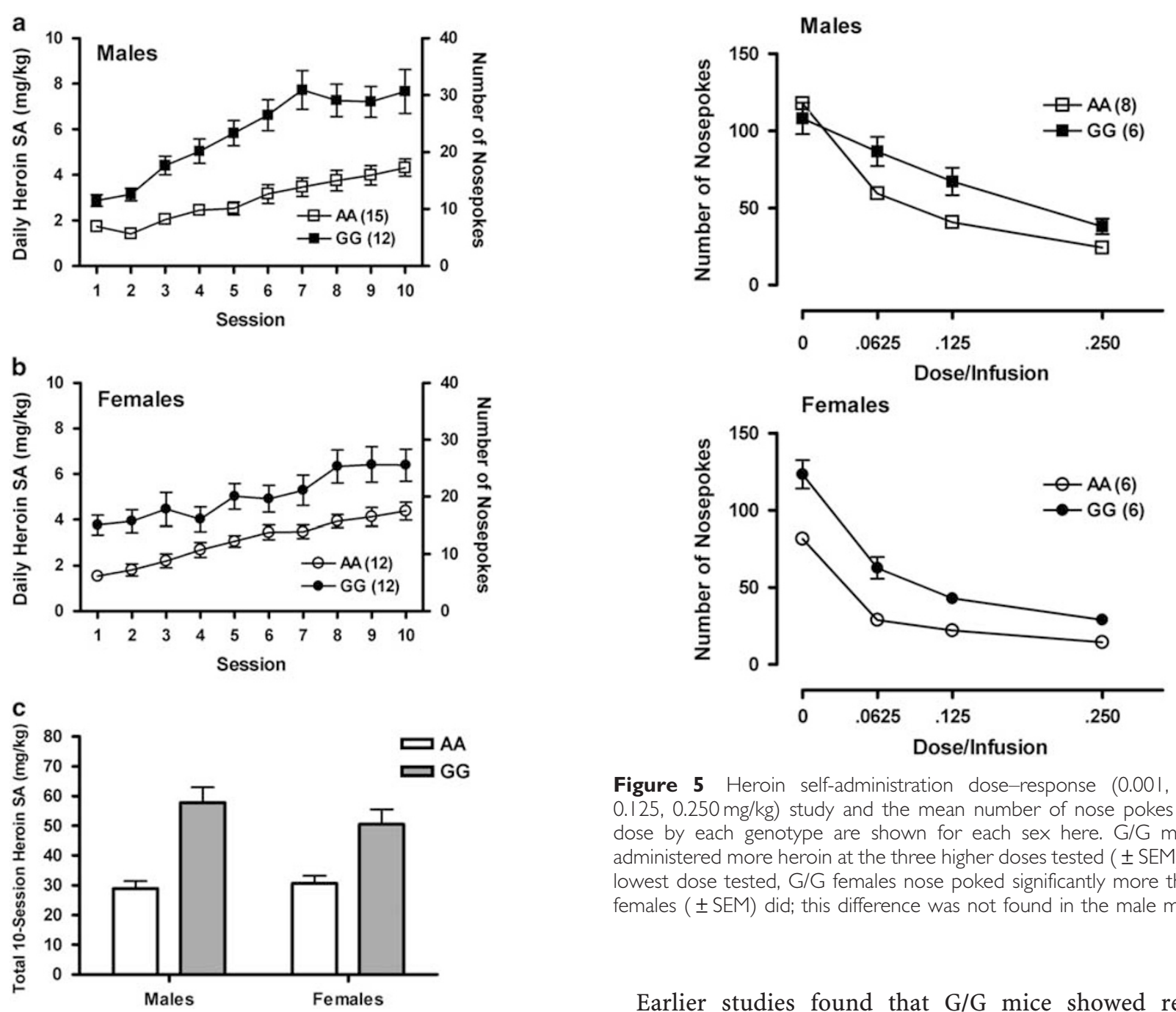

Figure 5 Heroin self-administration dose-response (0.00I, 0.0625 , $0.125,0.250 \mathrm{mg} / \mathrm{kg}$ ) study and the mean number of nose pokes at each dose by each genotype are shown for each sex here. G/G mice selfadministered more heroin at the three higher doses tested ( \pm SEM). At the lowest dose tested, G/G females nose poked significantly more than A/A females $( \pm$ SEM $)$ did; this difference was not found in the male mice.

Figure 4 The total daily heroin self-administered across the 10 extended 4-h sessions are shown. (a) Males of each genotype; (b) females in each genotype; (c) the total heroin taken across the 10 sessions.

attention in human genetic studies, and is associated with increased vulnerability to heroin addiction, based on several studies and meta-analyses (Haerian and Haerian, 2013). However, the mechanism for this 'risk' phenotype remains unclear, based in part on a lack of knowledge on the effects of this SNP on heroin reward per se, and also on the effects of this SNP on addiction trajectory. The present studies reveal for the first time that adult male and female $G / G$ mice (modelling the human 'risk' genotype) showed greater initial acquisition and escalation in heroin intake than A/A mice, over the course of 10-day extended access SA sessions. This increased heroin intake in G/G mice was robust, because it was found across several different heroin unit doses. However, there were no genotype or sex differences in extinction behavior following extended access to heroin self-administration. Baseline dopamine levels were equivalent across genotypes. We report for the first time that striatal dopamine levels in response to acute heroin administration differed by genotype, with G/G mice showing more robust heroin-induced increases in dopamine dialysates.

Earlier studies found that $G / G$ mice showed reduced mRNA expression and significant reductions of receptor protein levels (Mague et al, 2009), consistent with findings on human OPRM1, both in cell culture and in postmortem brain (Zhang et al, 2005). Additionally, there were other phenotypes found in G/G mice, including alterations in morphine-mediated antinociception, morphine-mediated hyperactivity, and development of locomotor sensitization (Mague et al, 2009). In vitro autoradiography studies found that $\mathrm{G} / \mathrm{G}$ mice exhibited lower $\left[{ }^{3} \mathrm{H}\right]$ DAMGO binding than A/A (wild-type) mice in the cingulate, motor, and insular cortices, nucleus accumbens core and shell, hypothalamus, thalamus, amygdala, periaqueductal gray, superficial gray of superior colliculus, and ventral tegmental area (Wang et al, 2012a; Wang et al, 2012b). These findings suggest that differential levels of MOPR expressed in brain regions involved in reward may, in part, lead to the differential behavioral effects found in G/G mice compared with the A/A mice.

MOPR are also known to regulate the rewarding properties of drugs of abuse in addition to MOPR agonists, including alcohol, nicotine and psychostimulants (eg, Contet et al, 2004; Charbogne et al, 2014). Complete lack of MOPR in constitutive global MOPR knockout mice led to failure in the development of conditioned place preference to morphine (as expected), and also decreases for conditioned place preference induced by alcohol and relatively 


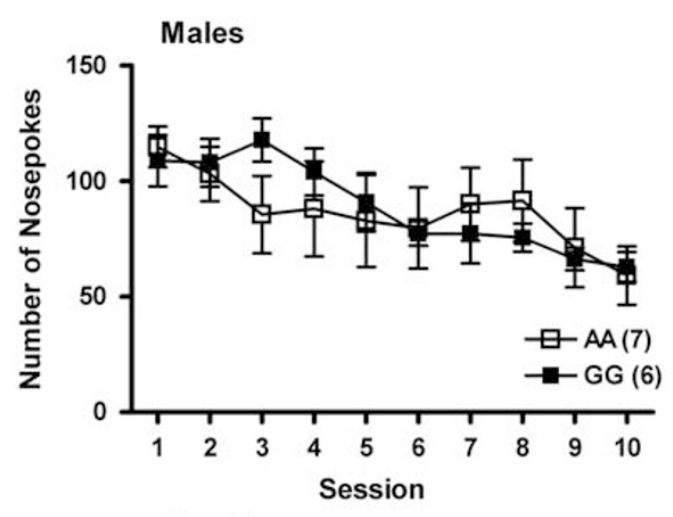

Females

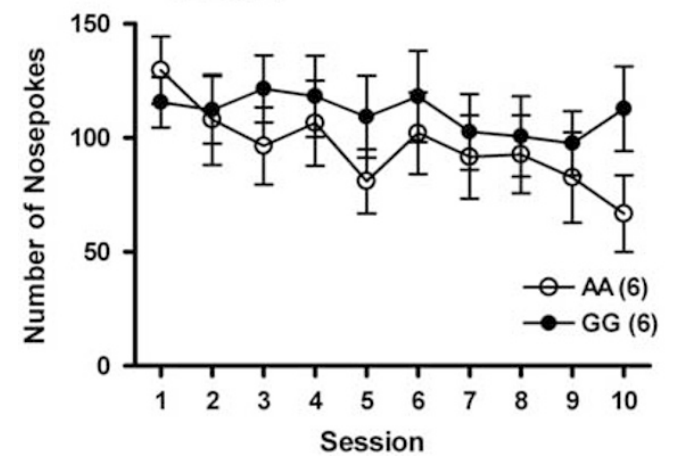

Figure 6 Extinction from extended access heroin self-administration over 10 sessions. Nose pokes at the formerly active hole across the 10 extinction trials are shown here. Extinction behavior of heroin selfadministration did not differ between the genotypes and sexes ( \pm SEM).

low doses of cocaine (Matthes et al, 1996; Sora et al, 1997; Becker et al, 2000; Sora et al, 2001). Further, MOPR knockout mice did not self-administer morphine (Becker et al, 2000) or alcohol (Roberts et al, 2000). However, recent studies suggest that global MOPR KO subjects exhibit a variety of other complex phenotypes in ethologically important functions, possibly based on compensatory adaptations (Lutz and Kieffer, 2013).

Escalation of heroin intake over the 10 daily heroin selfadministration sessions by G/G mice found in the current study suggests that the operant/instrumental reward circuitry mediated by MOPR activation is intact in the G/G mice. The higher intake of heroin by male and female G/G mice compared with wild-type litter mates may indicate the rewarding effect produced by heroin is stronger in the G/G mice than in A/A mice, and this is consistent with the increased dopaminergic response to specific heroin doses found herein. The rewarding effect produced by heroin, a MOPR agonist, is thought to be achieved at least partially by disinhibiting dopaminergic neurons in the ventral tegmental area and substantia nigra of the midbrain, thus increasing dopamine levels at the dopamine terminals in the striatum, nucleus accumbens and caudate putamen (Johnson and North, 1992).

Of interest, G/G mice have lower levels of MOPR compared with wild-type litter mates (Mague et al, 2009). Further, female G/G mice do not show conditioned reward to morphine in a place-preference study (Mague et al, 2009). This finding is in apparent contrast to the present robust
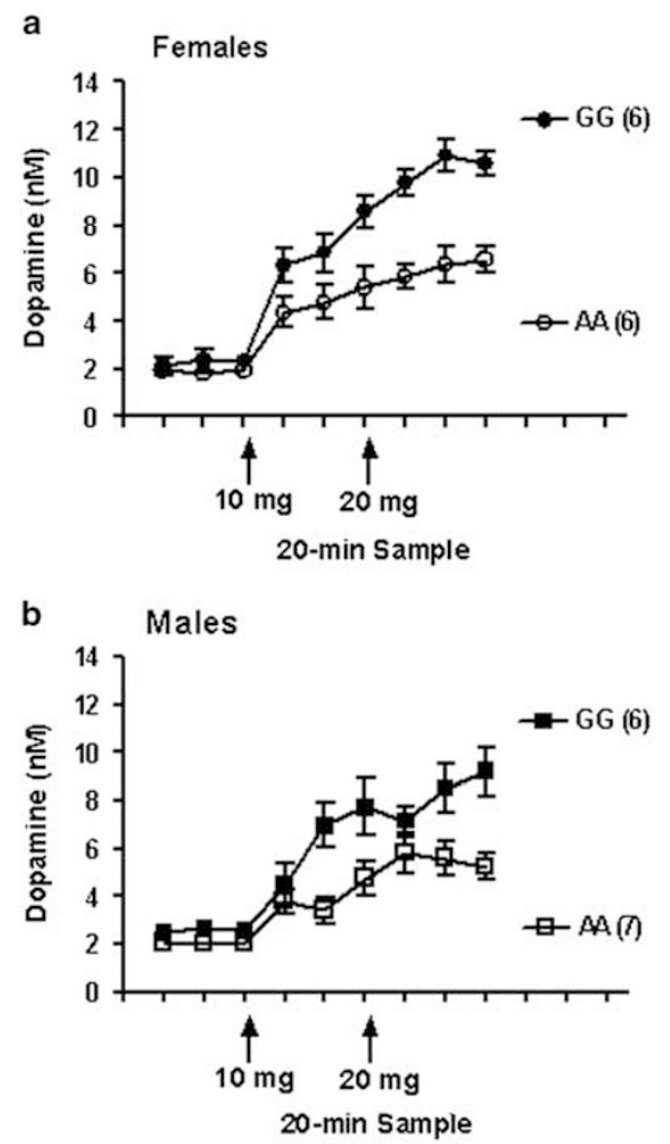

C

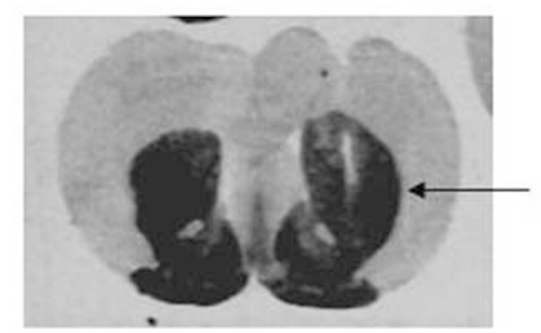

Figure 7 Absolute dopamine levels of the three baseline samples and levels of dopamine after heroin injection ( 10 and $20 \mathrm{mg} / \mathrm{kg}$ ) (Female, (a); Male, (b)). Dopamine levels were significantly higher in the $G / G$ mice compared with those of the A/A mice, after heroin injections (indicated by the arrows). In (c), a photomicrograph of a tissue section from a mouse used in this study shows the location of the microdialysis probe in the striatum.

reinforcing effects of heroin in G/G females (as well as males). However, this apparent discrepancy may be explained by the differential neuroanatomical/neurobiological substrates that mediate operant SA of MOPR agonist and conditioned place preference. Crucially, recent studies found that $\mathrm{G} / \mathrm{G}$ mice exhibited a complex set of genotypeand sex-dependent changes in MOPR Bmax, as well as MOPR signaling in the GTPgS assay across brain regions, including regions presumed to be involved in both operant and classic conditioning (Wang et al, 2012a; Wang et al, 2012b).

A further alternative explanation for the greater intake of heroin observed in the current study could be a 


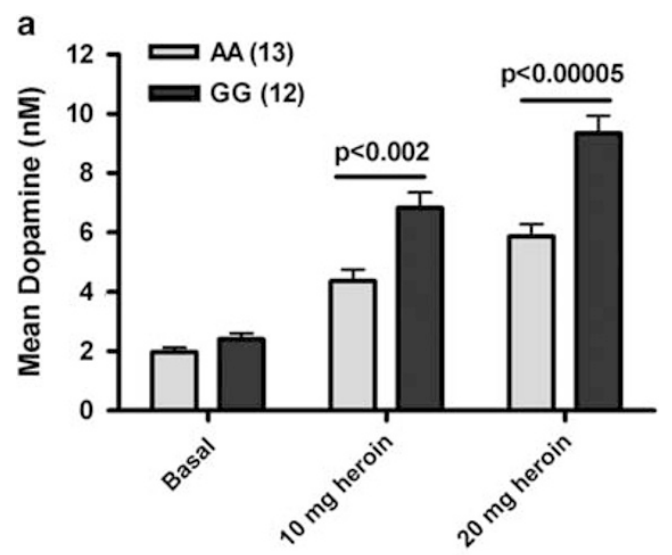

b AA Mice

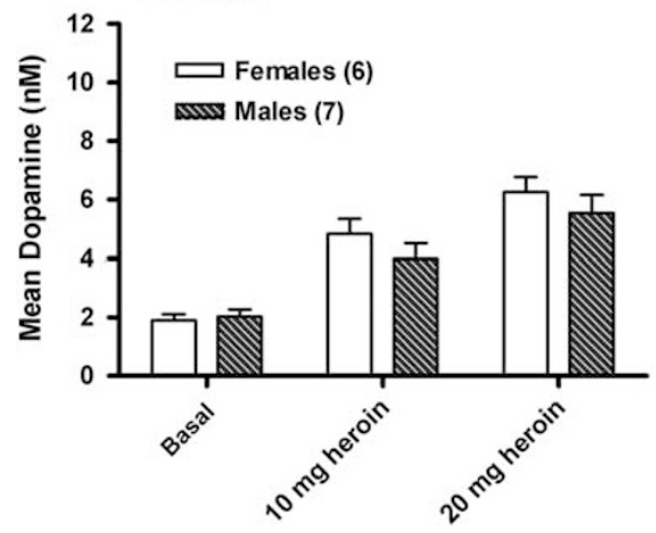

C

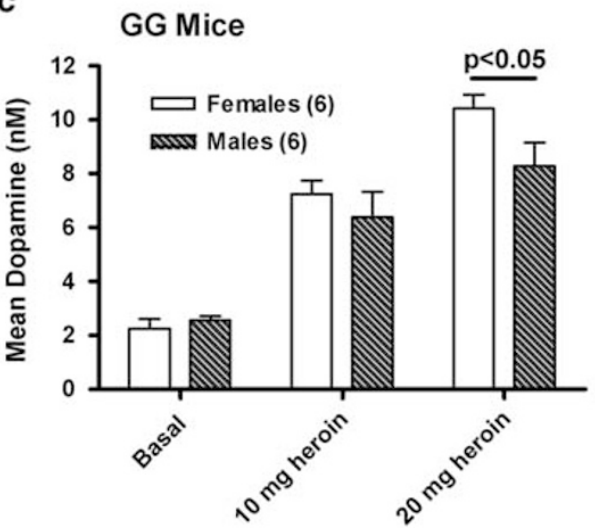

Figure 8 The mean hourly concentrations of absolute dopamine levels of the basal samples and absolute dopamine levels in response to each heroin injection are shown here. There was a significant main effect of Genotype and a significant effect of Condition. Ten micrograms per kilogram heroin-induced dopamine levels were higher in the G/G mice compared with the those of the A/A mice and $20 / \mathrm{kg}$ mg heroin-induced dopamine levels was also higher in the $G / G$ mice than in the A/A mice (a). There was also a significant Sex and Condition interaction (b and c). Dopamine levels induced by $20 / \mathrm{kg} \mathrm{mg}$ heroin were higher in the female mice than the male mice (c).

consequence of the lower rewarding effect of opioid agonists due to lower levels of MOPR in the reward circuitry of the G/G mice. Of interest, a prior study reported that heterozygous MOPR knockout mice, which have

approximately twofold smaller MOPR Bmax compared with wild types, had a decreased intake of morphine (a major active heroin metabolite) in an intravenous SA assay (Sora et al, 2001). G/G mice have also been reported to have reduced MOPR Bmax compared with wild types (Mague et al, 2009). However, G/G mice exhibited greater heroin intake than wild-type controls in these studies. Therefore, the greater heroin intake observed in G/G mice cannot be simply ascribed to the lower MOPR Bmax observed at baseline (not withstanding experimental differences between the present studies and the study of Sora et al (2001)).

Even though GG mice were found to have lower levels of MOPR (Mague et al, 2009) in some regions, heroin-induced dopamine increases in the striatum found in the study reported here were significantly higher than those of the AA mice. This seems congruent with findings from a 'humanized' A118G mice, which displayed fourfold greater dopamine response to alcohol administration (Ramchandani et al, 2011). It is well known that heroin induces dopamine release by disinhibiting GABAergic neurons in the midbrain. The reduced MOPR Bmax in the G/G mice compared with A/A mice (Mague et al, 2009) coupled with the higher dopamine levels induced by heroin in the G/G mice suggests that other mechanisms downstream of MOPR may play an important role in heroin-induced dopamine release in these mice. It may also suggest that other mechanisms rather than MOP-r activation are involved in the more robust dopamine response in the G/G mice.

Further studies are needed to examine how heroin SA affects MOPR expression in brain regions involved in mediating reward (eg, Porrino et al, 2007; Belin and Everitt, 2008). As MOPR levels are altered following MOPR agonist exposure (eg, Zhou et al, 2006; Theberge et al, 2012), it is possible that the present genotype-dependent difference is mediated by differences in the processes of MOPR adaptation caused by repeated heroin exposure, rather than by initial MOPR differences at baseline. Further studies would also be required to determine whether chronic heroin administration results in specific adaptations in heroininduced dopamine release in $\mathrm{G} / \mathrm{G}$ mice, to model effects that may occur at later points in the addiction trajectory.

Genetic variants in the human MOPR, particularly the A118G polymorphism, are associated with increased risk for heroin addiction (eg, Szeto et al, 2001; Bart et al, 2004; Kreek et al, 2005) and alcoholism (eg, Bart et al, 2005; Hendershot et al, 2014), and have also been reported to be associated with differential treatment responses involving different pain and addiction endpoints (eg, Bart et al, 2004; Kreek et al, 2005; Song et al, 2013; Boswell et al, 2013). Taken together, the A118G SNP was found to be associated with differential profiles, depending on the specific clinical phenotype studied; the complex pattern may possibly be explained by a differential impact of the SNP on MOPR in different brain areas, as reported in the A112G transgenic mouse model (Wang et al, 2012a; Wang et al, 2012b).

In summary, these are the first studies to model acquisition and escalation of heroin SA as well as its extinction in the A112G mouse model of the human A118G SNP. The present studies for the first time show that acquisition and escalation of heroin intake are greater in this construct. These findings therefore provide an advance in the translational analysis of the neurobiological mechanisms 
by which human carriers of the A118G SNP have an increased 'risk' trajectory of heroin/opioid addiction.

\section{FUNDING AND DISCLOSURE}

The authors declare no conflict of interest.

\section{ACKNOWLEDGEMENTS}

This work was supported by NIH 1R01DA029147 (YZ) and the Dr Miriam and Sheldon G. Adelson Medical Research Foundation (MJK). The author(s) declare that, except for income received from my primary employer, no financial support or compensation has been received from any individual or corporate entity over the past 3 years for research or professional service and there are no personal financial holdings that could be perceived as constituting a potential conflict of interest.

\section{REFERENCES}

Bart G, Heilig M, LaForge KS, Pollak L, Leal SM, Ott J et al (2004). Substantial attributable risk related to a functional mu-opioid receptor gene polymorphism in association with heroin addiction in central Sweden. Mol Psychiatry 9: 547-549.

Bart G, Kreek MJ, Ott J, LaForge KS, Proudnikov D, Pollak L et al (2005). Increased attributable risk related to a functional muopioid receptor gene polymorphism in association with alcohol dependence in central Sweden. Neuropsychopharmacology 30: 417-422.

Becker A, Grecksch G, Brodemann R, Kraus J, Peters B, Schroeder H et al (2000). Morphine self-administration in mu-opioid receptordeficient mice. Naunyn-Schmiedeberg's Arch Pharmacol 361: 584-589.

Belin D, Everitt BJ (2008). Cocaine seeking habits depend upon dopamine-dependent serial connectivity linking the ventral with the dorsal striatum. Neuron 57: 432-441.

Bond C, LaForge KS, Tian MT, Melia D, Zhang SW, Borg L et al (1998). Single-nucleotide polymorphism in the human mu opioid receptor gene alters beta-endorphin binding and activity: Possible implications for opiate addiction. Proc Natl Acad Sci USA 95: 9608-9613.

Boswell MV, Stauble ME, Loyd GE, Langman L, Ramey-Hartung B, Baumgartner RN et al (2013). The role of hydromorphone and OPRM1 in postoperative pain relief with hydrocodone. Pain Physician 16: 227-235.

Charbogne P, Kieffer BL, Befort K (2014). 15 years of genetic approaches in vivo for addiction research: Opioid receptor and peptide gene knockout in mouse models of drug abuse. Neuropharmacology 76 Pt B: 204-217.

Contet C, Kieffer BL, Befort K (2004). Mu opioid receptor: a gateway to drug addiction. Curr Opin Neurobiol 14: 370-378.

Franklin KBJ, Paxinos G (1997). The Mouse Brain in Stereotaxic Coordinates. Academic Press: New York.

Haerian BS, Haerian MS (2013). OPRM1 rs1799971 polymorphism and opioid dependence: evidence from a meta-analysis. Pharmacogenomics 14: 813-824.

Hendershot CS, Claus ED, Ramchandani VA (2014). Associations of OPRM1 A118G and alcohol sensitivity with intravenous alcohol self-administration in young adults. Addict Biol 2014: 20.

Huang MC, Schwandt ML, Ramchandani VA, George DT, Heilig M (2012). Impact of multiple types of childhood trauma exposure on risk of psychiatric comorbidity among alcoholic inpatients. Alcohol Clin Exp Res 36: 1099-1107.
Johnson SW, North RA (1992). Opioids excite dopamine neurons by hyperpolarization of local interneurons. J Neurosci 12: 483-488.

Kreek MJ, Bart G, Lilly C, LaForge KS, Nielsen DA (2005). Pharmacogenetics and human molecular genetics of opiate and cocaine addictions and their treatments. Pharmacol Rev 57: $1-26$.

Kroslak T, Laforge KS, Gianotti RJ, Ho A, Nielsen DA, Kreek MJ (2007). The single nucleotide polymorphism A118G alters functional properties of the human mu opioid receptor. J Neurochem 103: 77-87.

LaForge KS, Shick V, Spangler R, Proudnikov D, Yuferov V, Lysov Y et al (2000). Detection of single nucleotide polymorphisms of the human mu opioid receptor gene by hybridization or single nucleotide extension on custom oligonucleotide gelpad microchips: potential in studies of addiction. American J Med Genet 96: 604-615.

Lutz PE, Kieffer BL (2013). The multiple facets of opioid receptor function: implications for addiction. Curr Opin Neurobiol 23: 473-479.

Mague SD, Blendy JA (2010). OPRM1 SNP (A118G): involvement in disease development, treatment response, and animal models. Drug Alcohol Depend 108: 172-182.

Mague SD, Isiegas C, Huang P, Liu-Chen LY, Lerman C, Blendy JA (2009). Mouse model of OPRM1 (A118G) polymorphism has sex-specific effects on drug-mediated behavior. Proc Natl Acad Sci USA 106: 10847-10852.

Maisonneuve IM, Kreek MJ et al (1994). Acute tolerance to the dopamine response induced by a binge pattern of cocaine administration in male rats: an in vivo microdialysis study. J Pharmacol Exp Ther 268: 916-921.

Matthes HW, Maldonado R, Simonin F, Valverde O, Slowe S, Kitchen I et al (1996). Loss of morphine-induced analgesia, reward effect and withdrawal symptoms in mice lacking the mu-opioid-receptor gene. Nature 383: 819-823.

Porrino LJ, Smith HR, Nader MA, Beveridge TJ (2007). The effects of cocaine: a shifting target over the course of addiction. Prog Neuropsychopharmacol Biol Psychiatry 31: 1593-1600.

Ramchandani VA, Umhau J, Pavon FJ, Ruiz-Velasco V, Margas W, Sun $\mathrm{H}$ et al (2011). A genetic determinant of the striatal dopamine response to alcohol in men. Mol Psychiatry 16: 809-817 PMCID: PMC2925052.

Roberts AJ, McDonald JS, Heyser CJ, Kieffer BL, Matthes HW, Koob GF et al (2000). mu-Opioid receptor knockout mice do not self-administer alcohol. J Pharmacol Exp Ther 293: 1002-1008.

Song Z, Du B, Wang K, Shi X. (2013). Effects of OPRM1 A118G polymorphism on epidural analgesia with fentanyl during labor: a meta-analysis. Genet Test Mol Biomarkers 17: 743-749.

Sora I, Elmer G, Funada M, Pieper J, Li XF, Hall FS et al (2001). $\mathrm{Mu}$ opiate receptor gene dose effects on different morphine actions: evidence for differential in vivo mu receptor reserve. Neuropsychopharmacology 25: 41-54.

Sora I, Funada M, Uhl GR (1997). The mu-opioid receptor is necessary for [D-Pen2,D-Pen5] enkephalin-induced analgesia. Eur J Pharmacol 324: R1-R2.

Szeto CY, Tang NL, Lee DT, Stadlin A (2001). Association between $\mathrm{mu}$ opioid receptor gene polymorphisms and Chinese heroin addicts. Neuroreport 12: 1103-1106.

Theberge FR, Pickens CL, Goldart E, Fanous S, Hope BT, Liu QR et al (2012). Association of time-dependent changes in mu opioid receptor mRNA, but not BDNF, TrkB, or MeCP2 mRNA and protein expression in the rat nucleus accumbens with incubation of heroin craving. Psychopharmacology (Berl) 224: 559-571.

Wang YJ, Huang P, Blendy JA, Liu-Chen LY (2012a). Brain regionand sex-specific alterations in DAMGO-stimulated [(35) S]GTPgammaS binding in mice with Oprm1 G/G. Addict Biol 19: $354-361$. 
Wang YJ, Huang P, Ung A, Blendy JA, Liu-Chen LY (2012b). Reduced expression of the mu opioid receptor in some, but not all, brain regions in mice with OPRM1 G/G. Neuroscience 205: 178-184.

Weerts EM, McCaul ME, Kuwabara H, Yang X, Xu X, Dannals RF et al (2013). Influence of OPRM1 Asn40Asp variant (A118G) on [11C]carfentanil binding potential: preliminary findings in human subjects. Int J Neuropsychopharmacol 16: 47-53.

Zhang Y, Mayer-Blackwell B, Schlussman SD, Randesi M, Butelman ER, Ho A et al (2013). Extended access oxycodone self-administration and neurotransmitter receptor gene expression in the dorsal striatum of adult C57BL/6 J mice. Psychopharmacology (Berl) 231: 1277-1287.

Zhang Y, Schlussman SD, Ho A, Kreek MJ (2001). Effect of acute binge cocaine on levels of extracellular dopamine in the caudate putamen and nucleus accumbens in male (57BL/6J and 129/J mice. Brain Res. 923: 172-177.
Zhang Y, Schlussman SD, Ho A, Kreek MJ (2003). Effect of chronic 'binge cocaine' on basal levels and cocaine-induced increases of dopamine in the caudate putamen and nucleus accumbens of C57BL/6J and 129/J mice. Synapse 50: 191-199.

Zhang Y, Svenningsson P, Picetti R, Schlussman SD, Nairn AC, Ho A et al (2006). Cocaine self-administration in mice is inversely related to phosphorylation at Thr34 (protein kinase A site) and Ser130 (kinase CK1 site) of DARPP-32. J Neurosci 26: 2645-2651.

Zhang Y, Wang D, Johnson AD, Papp AC, Sadee W (2005). Allelic expression imbalance of human mu opioid receptor (OPRM1) caused by variant A118G. J Biol Chem 280: 32618-32624.

Zhou Y, Bendor J, Hofmann L, Randesi M, Ho A, Kreek MJ (2006). $\mathrm{Mu}$ opioid receptor and orexin/hypocretin mRNA levels in the lateral hypothalamus and striatum are enhanced by morphine withdrawal. J Endocrinol 191: 137-145. 